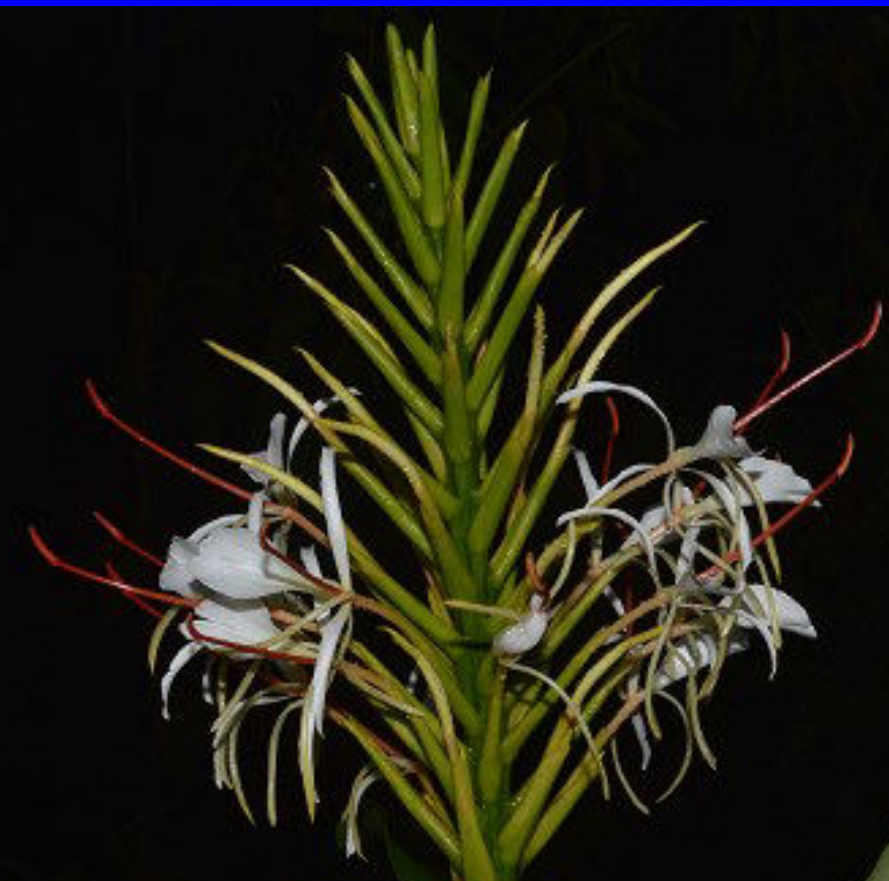

BJP

Bangladesh Journal of Pharmacology

Research Article

\title{
Composition, antibacterial and anti- oxidant potentials of the essential oil of Hedychium matthewii
}


Abstracted/indexed in Academic Search Complete, Asia Journals Online, Bangladesh Journals Online, Biological Abstracts, BIOSIS Previews, CAB Abstracts, Current Abstracts, Directory of Open Access Journals, EMBASE/Excerpta Medica, Google Scholar, HINARI (WHO), International Pharmaceutical Abstracts, Open J-gate, Science Citation Index Expanded, SCOPUS and Social Sciences Citation Index;

ISSN: $1991-0088$

\title{
Composition, antibacterial and anti-oxidant potentials of the essential oil of Hedychium matthewii
}

\author{
Sinjumol Thomas ${ }^{1}$ and Bince Mani $^{2}$ \\ ${ }^{1}$ Department of Botany, Vimala College, Thrissur 680009, Kerala, India; ${ }^{2}$ Postgraduate and Research Department of \\ Botany, St. Thomas College Palai, Kottayam 686574, Kerala, India.
}

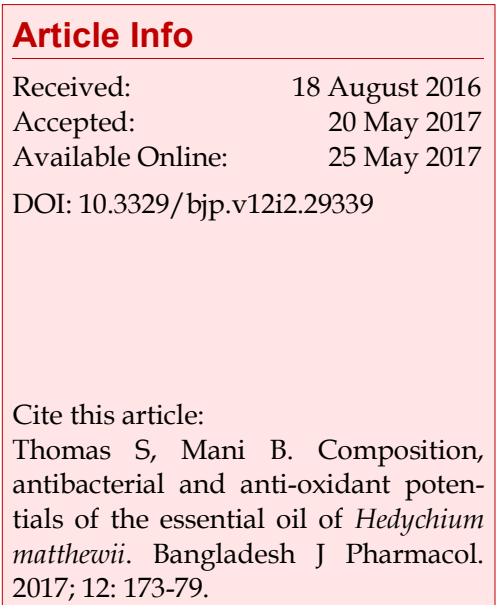

\begin{abstract}
Essential oils are known for their medicinal value since time immemorial and continue to be of vital importance until the present day. The present study describes the composition, antibacterial and anti-oxidant potential of rhizome oil of Hedychium matthewii. Thirty-five constituents of the oil were identified to account for $82.7 \%$, of which $85.7 \%$ was monoterpes and the rest were sesquiterpnes. Most of the major constituents were alcohols and linalool was the prominent one $(45.7 \%)$. The antibacterial assay showed the bactericidal effect of the essential oil and the most susceptible organism was Streptococcus hemolyticus with a zone of inhibition of $33.8 \pm 1.7 \mathrm{~mm}$. The reducing power and nitric oxide scavenging activity of the essential oil was far exceeding the reference compound ascorbic acid and it could be the sign of the potential anti -oxidant power of the oil isolated. The present study also revealed the prospective of $H$. matthewii as a new natural source of linalool, which has medicinal and various industrial applications.
\end{abstract}

\section{Introduction}

The genus Hedychium, an ornamental and ethnomedicinal plant comprises about 90 species, mostly distributed from India to South-East Asia (Raj et al., 2005; Thomas et al., 2015). Hedychium species are a good source of various essential oil compounds having medicinal and other industrial applications (Sakhanokho et al., 2013). The essential oil obtained from leaves of $H$. coronarium constituted $\beta$-pinene as the major compound (Raj et al., 2013), whereas $\beta$-ocimene and linalool as the major constituents in its flower oil (Báez et al., 2011) and 1,8 cineole as the major compound in rhizome oil (Joy et al., 2007).

Leaf and flower essential oils of $H$. gardnarianum reported the presence of $a$ and $\beta$-pinenes as the major components (Medeiros et al., 2003). H. flavum was characterized by 1,8 cineole and linalool as major compounds in the essential oil obtained from the inflorescence (Báez et al., 2011). Rhizome oil of $H$. larsenii was dominated by linalool (Raj et al., 2005), whereas leaf and inflorescence oil dominated by arcurcumin and p-cymene, respectively (Raj et al., 2013). It has been reported that rhizome oil of $H$. thyrsiforme, H. flavum and H. bousigonianum were dominated by 1,8 cineole, whereas linalool was the major constituent in $H$. forrestii and $H$. coccineum. $\beta$-Pinene was also found to be the major rhizome oil component in $H$. elatum and $H$. flavescens (Sakhanokho et al., 2013).

Essential oils obtained from $H$. spicatum, H. aurantiacum, $H$. coronarium and $H$. ellipticum exhibited good antioxidant potentials by quenching DPPH radicals and moderate to good $\mathrm{Fe}^{2+}$ chelating activity and may perhaps afford protection against oxidative damage (Joshi et al., 2008). Flower and leaf oils of $H$. gardnerianum showed good antimicrobial activity against Staphylococcus aureus and Staphylococcus epidermidis (Medeiros et al., 2003). The rhizome essential 
oil and solvent extracts of $H$. flavescens, $H$. venustum, $H$. ellipticum, $H$. aurantiacum and $H$. coronarium showed a broad spectrum antimicrobial activity (Joshi et al., 2008; Joy et al., 2007; Sabulal et al., 2007). Essential oil of $H$. spicatum is reported to possess antimicrobial and antioxidant activity (Bishtet al., 2006; Joshi et al., 2008). Therefore, Hedychium species not only have ornamental value but also have medicinal and industrial value.

Hedychium matthewii, a recently reported taxon, is known only from Idukki, Kerala (Thomas et al., 2015). There are no reports available on the essential oil composition and their biological property of this species. Therefore, the present study aimed at analyses the composition, antibacterial and anti-oxidant potential of the essential oil isolated from rhizomes of this least studied taxon.

\section{Materials and Methods}

\section{Plant material}

The rhizomes of $H$. matthewii were collected from two populations at Idukki and brought to the laboratory and washed to remove adhering soil and dust particles. The rhizomes were cut into pieces and dried at room temperature. A voucher specimen (RHT65200) deposited in The Rapinat Herbarium (RHT), St. Joseph's College, Tiruchirappalli, Tamilnadu.

\section{Chemicals}

1, 1- Diphenyl-2-picrylhydrazyl (DPPH), sodium nitrite, sulfanilamide and ascorbic acid (AA) were purchased from Sigma chemical co. (USA). Potassium ferricyanide, trichloroacetic acid (TCA), sodium nitroprusside, anapthyl-ethylenediamine and ferric chloride were purchased from Merck chemical supplies (Germany). All the chemicals used including the solvents, were of analytical grade.

\section{Essential oil extraction}

The dried rhizomes (25 g) were ground and hydrodistilled for 3 hours using a Clevenger-type apparatus. The distillate was dried over anhydrous sodium sulfate and stored in tightly closed vials at $4^{\circ} \mathrm{C}$ for analysis. The essential oil content was determined as a percentage on dry weight basis as an average of three independent extractions of each sample.

\section{Characterization and identification of essential oil constituents}

GC/MS analyses were performed using Shimadzu GC2010 gas chromatograph (GC-FID) equipped with QP 2010 mass spectrometer (MS). Approximately $0.1 \mu \mathrm{L}$ of pure oil sample was subjected to gas chromatography (GC) and gas chromatography/mass spectrometry (GC/MS) analysis. The column used was DB-5. The oven temperature was programmed as follows; $70^{\circ} \mathrm{C}$ for $5 \mathrm{~min}$ and then increased to $110^{\circ} \mathrm{C}$ at the rate of $5^{\circ} \mathrm{C} /$ min, then up to $200^{\circ} \mathrm{C}$ at the rate of $3^{\circ} \mathrm{C} / \mathrm{min}$ and again up to $220^{\circ} \mathrm{C}$ at the rate of $5^{\circ} \mathrm{C} / \mathrm{min}$, at which the column was maintained for $5 \mathrm{~min}$; injector temperature of $250^{\circ}$ C. Helium was used as carrier gas at a flow rate of 1 $\mathrm{mL} / \mathrm{min}$. Identification of the individual components was made by matching their recorded mass spectra and linear retention indices with the library (NIST and Wiley) provided by the instrument software, online database (http://webbook.nist.gov/chemistry; http:/ / www.flavornet.org) and by comparing their calculated retention indices with literature value (Adams, 2009).

\section{Test microorganisms}

The bacterial strains used in the study were three gram positive, namely, Streptococcus haemolyticus (MTCC442), Bacillus cereus (MTCC430) and Staphylococcus aureus (MTCC87) and nine gram negative, namely, Vibrio parahaemolyticus (MTCC451), Vibrio cholerae (MTCC3904), Salmonella paratyphi (MTCC735), Enterobacter aerogens (MTCC111), Escherichia coli (MTCC433), Klebsiella pneumoniae (MTCC3384), Proteus vulgaris (MTCC426), Salmonella typhi (MTCC733) and Pseudomonas aeruginosa (MTCC741). All the tested strains are reference strains, and were collected from Microbial Type Culture Collection and Gene Bank, Institute of Microbial Technology, Sector 39-A, Chandigarh 160036, India.

\section{Antibacterial activity test}

The antibacterial activity of essential oil was carried out by disc diffusion method (Bauer, 1966), recommended by clinical and laboratory standards institute (CLSI), using $25 \mu \mathrm{L}$ of standardized suspension of test bacteria $\left(1.5^{*} 10^{8} \mathrm{CFU} / \mathrm{mL}\right)$ spread on Mueller-Hinton agar (MHA, pH $7.3 \pm 0.1$ ) plates. The discs $(6 \mathrm{~mm}$ in diameter) were impregnated with $20 \mu \mathrm{L}$ of essential oil, followed by air-drying and were placed on seeded agar plates. Amoxicillin (30 $\mu \mathrm{g} /$ disc) was used as positive control to determine the sensitivity of bacterial strain. The plates were incubated at $37^{\circ} \mathrm{C}$ for 24 hours. Antimicrobial activity was evaluated by measuring the zones of inhibition against the tested bacteria. Each assay was carried out in triplicate.

\section{Determination of reducing power}

The reducing power of the essential oil was measured by making use of the method described by Yen and Duh (1993) with some modifications. Various concentrations $(10,20,30,40$ and $50 \mu \mathrm{L} / \mathrm{mL})$ of essential oil in methanol were taken separately and mixed with $2.5 \mathrm{~mL}$ of $0.2 \mathrm{M}$ sodium phosphate buffer ( $\mathrm{pH}$ 6.6). The dilute sample was then mixed with $5.0 \mathrm{~mL}$ of $1 \%$ potassium ferricyanide and the mixture was incubated at $50^{\circ} \mathrm{C}$ for $20 \mathrm{~min} 5.0 \mathrm{~mL}$ of $10 \%$ trichloroacetic acid was added to the mixture and was centrifuged at 3000 
rpm for $10 \mathrm{~min} 5.0 \mathrm{~mL}$ of the supernatant solution was mixed with $5.0 \mathrm{~mL}$ of distilled water and $1.0 \mathrm{~mL}$ of ferric chloride $(1 \%)$. The absorbance was measured spectrophotometrically at $700 \mathrm{~nm}$ (Shimadzu, UV-15002). The ascorbic acid standard was used for comparison.

\section{DPPH radical scavenging activity}

The free radical scavenging activity of essential oil was measured using the stable DPPH radical, according to the method of Blois (Mani and Thomas, 2014) with minor modifications. Briefly, $0.1 \mathrm{mM}$ solution of DPPH in methanol was prepared and this solution $(1 \mathrm{~mL})$ was added to essential oil in methanol $(3 \mathrm{~mL})$ at concentrations ranging from $10-50 \mu \mathrm{L} / \mathrm{mL}$. The mixture was shaken well and left to stand for $30 \mathrm{~min}$ in the dark and the absorbance was then measured at $517 \mathrm{~nm}$. The capability to scavenge the DPPH radical was calculated using the following formula:

$$
(\%)=\left(\left(\mathrm{A}_{0}-\mathrm{A}_{1}\right) / \mathrm{A}_{0}\right) \times 100
$$

Where, $A_{0}$ and $A_{1}$ are absorbance of the control and of the sample, respectively. Ascorbic acid was used as reference.

\section{Nitric oxide (NO) scavenging activity}

Nitric oxide scavenging effect was determined according to Griess Illosvoy reaction (Johnson, 1964) with slight modification. The reaction mixture contained: $10 \mathrm{mM}$ SNP in $0.5 \mathrm{M}$ phosphate buffer ( $\mathrm{pH} 7.4)$ and various doses $(10-50 \mu \mathrm{L} / \mathrm{mL})$ of the essential oil in a final volume of $3 \mathrm{~mL}$. After incubation for $60 \mathrm{~min}$ at $37^{\circ}$ C, Griess reagent ( $0.1 \%$ a-napthyl-ethylenediamine in distilled water and $1 \%$ sulphanilamide in $5 \% \mathrm{H}_{3} \mathrm{PO}_{4}$ ) was added. The pink chromophore generated during diazotization of nitrite ions with sulphanilamide and subsequent coupling with a-napthyl-ethylenediamine was measured spectrophotometrically at $540 \mathrm{~nm}$. Ascorbic acid was used as a positive control. Nitric oxide scavenging ability (\%) was calculated by using the equation (1).

\section{Statistical analysis}

Experimental results were expressed as the mean \pm standard deviation (SD) of the number of experiments indicated in the legends. Statistical significance was tested using a one way analysis of variance (ANOVA) followed by an LSD test, where $\mathrm{p}<0.05$ was considered significant.

\section{Results}

\section{Essential oil characterization}

The dried rhizomes were hydrodistilled to obtain a pleasant smelling, pale yellow oil at a yield of $2.6 \%$. The gas chromatogram (GC) of the rhizome essential oil of
H. matthewii is shown in Figure 1. The GC profile indicates the presence of more than 50 compounds, of which 35 were identified by comparing and matching the mass spectra and GC retention index (RI) of the compounds with those of reference.

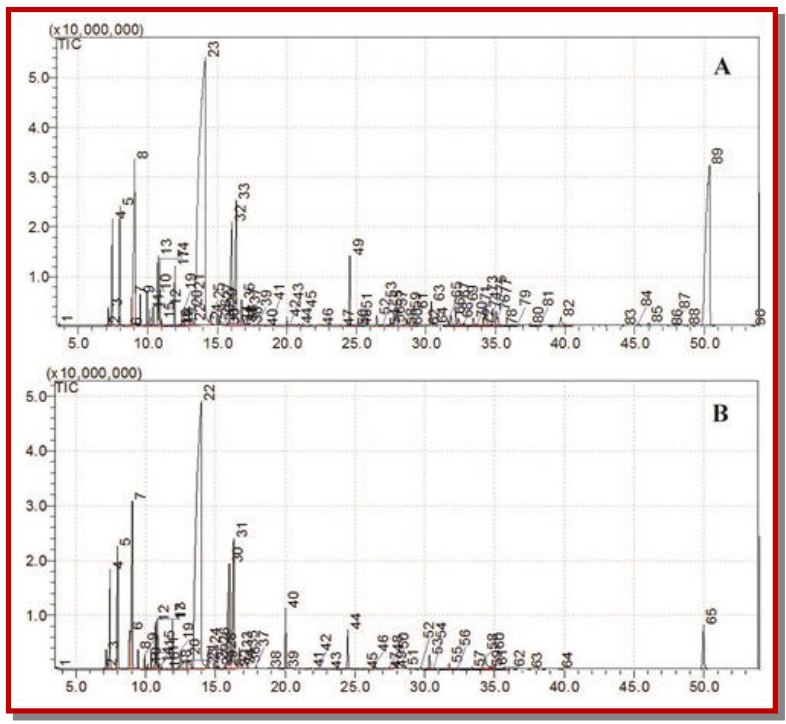

Figure 1: Total ion chromatogram (TIC) of the volatile compounds from the dried rhizomes of two populations (A and B) of $H$. matthewii

Table I depicts the volatile components indentified and those 35 compounds accounting for $82.7 \%$ of the oil hydrodistilled from the dried rhizome. $85.7 \%$ of the oil consisted of monoterpenes whereas rests (14.3\%) accounted for sesquiterpenes. The constituents indentified consisted of fourteen monoterpene hydrocarbons $(40 \%)$, sixteen oxygenated monoterpenes (45.7\%), two sesquiterpene hydrocarbons $(5.7 \%)$ and three oxygenated sesquiterpenes $(8.6 \%)$. The analyzed oil contained esters, oxides, alcohols, phenols, aldehydes and ketones. The majority of essential oil constituents were found in the monoterpene class where the most prominent compounds were linalool $(45.6 \%)$ followed by $\beta$-pinene $(6.5 \%)$, borneol $(6.3 \%)$, 4-terpineol $(5.6 \%)$, camphene $(3.3 \%)$ and $\alpha$-pinene $(2.5 \%)$.

\section{Antibacterial assay}

The results of the antibacterial studies, of the essential oil obtained, by the disc diffusion technique are given in Table II. By analyzing the antibacterial activity of essential oil, we observed that all the bacteria tested were susceptible and the essential oil showed hopeful antibacterial activity. A volume of $20 \mu \mathrm{L}$ of essential oil showed nearly equal and effective inhibition against all the strains used in the present study. The most susceptible bacterium tested was Streptococcus haemolyticus with a zone of inhibition of $33.8 \pm 1.7 \mathrm{~mm}$. The bacteria such as S. haemolyticus and Vibrio cholerae were more susceptible towards essential oil than 


\begin{tabular}{|c|c|c|c|c|}
\hline \multicolumn{5}{|c|}{ Table I } \\
\hline \multicolumn{5}{|c|}{$\begin{array}{c}\text { Chemical composition of the essential oil from } \\
\text { H. matthewii }\end{array}$} \\
\hline $\begin{array}{l}\text { SL. } \\
\text { No. }\end{array}$ & Component & $\mathrm{RI}_{\mathrm{a}}$ & $\mathrm{RI}_{\mathrm{b}}$ & $\begin{array}{l}\text { Composition } \\
(\%)\end{array}$ \\
\hline 1 & a-Thujene & 930 & 931 & $0.4 \pm 0.1$ \\
\hline 2 & a-Pinene & 938 & 939 & $2.5 \pm 0.5$ \\
\hline 3 & Camphene & 953 & 953 & $3.3 \pm 0.9$ \\
\hline 4 & Sabinene & 972 & 972 & $1.2 \pm 0.5$ \\
\hline 5 & $\beta$-Pinene & 981 & 980 & $6.5 \pm 0.8$ \\
\hline 6 & $\beta$-Myrcene & 992 & 992 & $0.5 \pm 0.04$ \\
\hline 7 & a-Phellandrene & 1007 & 1005 & $0.5 \pm 0.2$ \\
\hline 8 & 3-Careen & 1111 & 1011 & $0.2 \pm 0.1$ \\
\hline 9 & a-Terpinene & 1012 & 1012 & $0.4 \pm 0.05$ \\
\hline 10 & o-Cymene & 1026 & 1027 & $1.4 \pm 0.1$ \\
\hline 11 & D-Limonene & 1031 & 1031 & $1.2 \pm 0.03$ \\
\hline 12 & 1,8-Cineole & 1033 & 1033 & $0.1 \pm 0.02$ \\
\hline 13 & trans- $\beta$-Ocimene & 1050 & 1050 & $0.1 \pm 0.1$ \\
\hline 14 & $\gamma$-Terpinene & 1059 & 1059 & $1.2 \pm 0.1$ \\
\hline 15 & a-Terpinolene & 1063 & 1063 & $0.5 \pm 0.2$ \\
\hline 16 & $\begin{array}{l}\text { trans-Linalool } \\
\text { oxide }\end{array}$ & 1065 & 1065 & $0.7 \pm 0.5$ \\
\hline 17 & Linalool & 1098 & 1098 & $45.6 \pm 3.9$ \\
\hline 18 & Fenchol & 1112 & 1112 & $0.02 \pm 0.0$ \\
\hline 19 & $p$-Menth-2-en-1-ol & 1120 & 1121 & $0.2 \pm 0.05$ \\
\hline 20 & L-Camphor & 1140 & 1139 & $0.1 \pm 0.01$ \\
\hline 21 & Borneol & 1163 & 1162 & $6.3 \pm 1.7$ \\
\hline 22 & 4-Terpineol & 1180 & 1180 & $5.6 \pm 1.5$ \\
\hline 23 & a-Terpineol & 1189 & 1189 & $0.7 \pm 0.1$ \\
\hline 24 & Myrtenal & 1190 & 1190 & $0.2 \pm 0.03$ \\
\hline 25 & $\begin{array}{l}\text { a-Phellandrene } \\
\text { epoxide }\end{array}$ & 1192 & 1192 & $0.1 \pm 0.1$ \\
\hline 26 & Piperitol & 1199 & 1198 & $0.2 \pm 0.1$ \\
\hline 27 & Bornyl fomate & 1232 & 1232 & $0.1 \pm 0.01$ \\
\hline 28 & Bornyl acetate & 1283 & 1283 & $1.1 \pm 1.0$ \\
\hline 29 & Thymol & 1284 & 1284 & $0.1 \pm 0.02$ \\
\hline 30 & a-Terpinyl acetate & 1352 & 1352 & $0.03 \pm 0.0$ \\
\hline 31 & $\beta$-Caryophyllene & 1418 & 1418 & $0.1 \pm 0.1$ \\
\hline 32 & a-Cedrene & 1433 & 1433 & $0.2 \pm 0.1$ \\
\hline 33 & $\begin{array}{l}\text { Caryophyllene } \\
\text { oxide }\end{array}$ & 1583 & 1583 & $0.1 \pm 0.1$ \\
\hline 34 & Guaiol & 1597 & 1597 & $0.5 \pm 0.2$ \\
\hline 35 & $\begin{array}{l}\text { 10-epi- } \gamma- \\
\text { Eudesmol }\end{array}$ & 1619 & 1619 & $0.5 \pm 0.2$ \\
\hline
\end{tabular}

Values are mean $\pm \mathrm{SD}$ of two samples $(\mathrm{n}=2)$; $\mathrm{RI}_{\mathrm{a}}$ and $\mathrm{RI}_{\mathrm{b}}$ : Experimental and reference retention indices

antibiotic tested. The results also showed that the essential oil was found to be effective antibacterial

\begin{tabular}{|c|c|c|}
\hline \multicolumn{3}{|c|}{ Table II } \\
\hline \multicolumn{3}{|c|}{$\begin{array}{l}\text { Antibacterial activity of the essential oil from } \\
\text { H. matthewii }\end{array}$} \\
\hline \multirow[t]{2}{*}{ Species } & \multicolumn{2}{|c|}{ Zone of inhibition (mm) } \\
\hline & $\begin{array}{l}\text { Essential } \\
\text { oil }\end{array}$ & Amoxicillin \\
\hline \multicolumn{3}{|l|}{ Gram positive } \\
\hline Bacillus cereus & $19.3 \pm 0.9$ & $28.3 \pm 0.6$ \\
\hline Staphylococcus aureus & $29.2 \pm 0.8$ & $30.2 \pm 0.3$ \\
\hline Streptococcus hemolyticus & $33.8 \pm 1.7$ & $31.5 \pm 0.9$ \\
\hline \multicolumn{3}{|l|}{ Gram negative } \\
\hline Enterobacter aerogens & $20.6 \pm 1.5$ & $27.8 \pm 0.3$ \\
\hline Salmonella paratyphi & $23.8 \pm 1.2$ & $30.5 \pm 0.5$ \\
\hline Vibrio cholerae & $30.6 \pm 1.04$ & $27.8 \pm 0.3$ \\
\hline Salmonella typhii & $28.0 \pm 1.7$ & $34.3 \pm 0.8$ \\
\hline Escherichia coli & $21.0 \pm 1.0$ & $30.5 \pm 0.9$ \\
\hline Vibrio parahaemolyticus & $26.3 \pm 1.5$ & $32.3 \pm 0.6$ \\
\hline Proteus vulgaris & $28.2 \pm 1.7$ & $32.2 \pm 0.3$ \\
\hline Klebsiella pneumoniae & $24.2 \pm 1.04$ & $26.0 \pm 0.9$ \\
\hline Pseudomonas aeruginosa & $26.2 \pm 1.6$ & $28.3 \pm 0.6$ \\
\hline
\end{tabular}

Values are presented as mean \pm SD of triplicate experiments

agent as the standard antibiotic used in the study. Moreover, the essential oil inhibited the growth of both gram positive and gram negative bacteria; consequently it may be used as a broad spectrum natural antibacterial agent.

\section{Anti-oxidant assay}

Reducing power: The reducing power of a compound or extract was related to its electron transfer ability and might, therefore, served as an indicator of its potential anti-oxidant activity. The reducing power of the essential oil and ascorbic acid increased with the concentration (Figure 2). The oil exhibited significantly higher activity than the standard ascorbic acid. The results of the present study suggest that essential oil isolated from $H$. matthewii has potent reducing power and promising anti-oxidant activity.

\section{DPPH radical scavenging}

DPPH radical scavenging assay, commonly used for analyzing the radical scavenging ability of a compound or extract, is simple and highly sensitive (Miguel, 2010). The anti-oxidant potential of the essential oil obtained from $H$. matthewii was studied by analyzing the radical scavenging capacity and electron donating ability of the constituents in the essential oil. The DPPH radical scavenging activity of the essential oil and standard anti -oxidative compound (ascorbic acid) is shown in Table III. The result showed a dose-dependent inhibition of $\mathrm{DPHH}$ radical by both oil and the standard and there was no significant difference exists between the 
Table III

DPPH radical and nitric oxide scavenging activityof rhizome oil of $H$. matthewii

\begin{tabular}{|lccccc|}
\hline & \multicolumn{5}{c}{ Concentration $(\mu \mathrm{L} / \mathrm{mL})$} \\
\cline { 2 - 6 } DPPH radical & 10 & 20 & 30 & 40 & 50 \\
Ascorbic acid $(\mu \mathrm{g} / \mathrm{mL})$ & $12.6 \pm 0.1^{\mathrm{a}}$ & $30.4 \pm 0.1^{\mathrm{a}}$ & $49.2 \pm 0.1^{\mathrm{a}}$ & $72.5 \pm 0.1^{\mathrm{a}}$ & $97.4 \pm 0.1^{\mathrm{a}}$ \\
Essential oil $(\mu \mathrm{L} / \mathrm{mL})$ & $10.8 \pm 0.1^{\mathrm{a}}$ & $27.5 \pm 0.2^{\mathrm{a}}$ & $46.7 \pm 0.1^{\mathrm{a}}$ & $70.1 \pm 0.2^{\mathrm{a}}$ & $91.1^{\mathrm{a}} \pm 0.1^{\mathrm{a}}$ \\
Nitric oxide & & & & \\
Ascorbic acid $(\mu \mathrm{g} / \mathrm{mL})$ & $10.3 \pm 0.2^{\mathrm{a}}$ & $21.2 \pm 0.1^{\mathrm{a}}$ & $32.6 \pm 0.1^{\mathrm{a}}$ & $41.1 \pm 0.2^{\mathrm{a}}$ & $52.2^{\mathrm{a}} \pm 0.1^{\mathrm{a}}$ \\
Essential oil $(\mu \mathrm{L} / \mathrm{mL})$ & $16.8 \pm 0.1^{\mathrm{b}}$ & $35.3 \pm 0.1^{\mathrm{b}}$ & $54.1 \pm 0.1^{\mathrm{b}}$ & $72.8 \pm 0.1^{\mathrm{b}}$ & $94.3 \pm 0.3^{\mathrm{b}}$ \\
\hline
\end{tabular}

Values are mean \pm SD of two samples analyzed individually in triplicate. Superscripts with the same letters within each column are not significantly different at $\mathrm{p}<0.05$

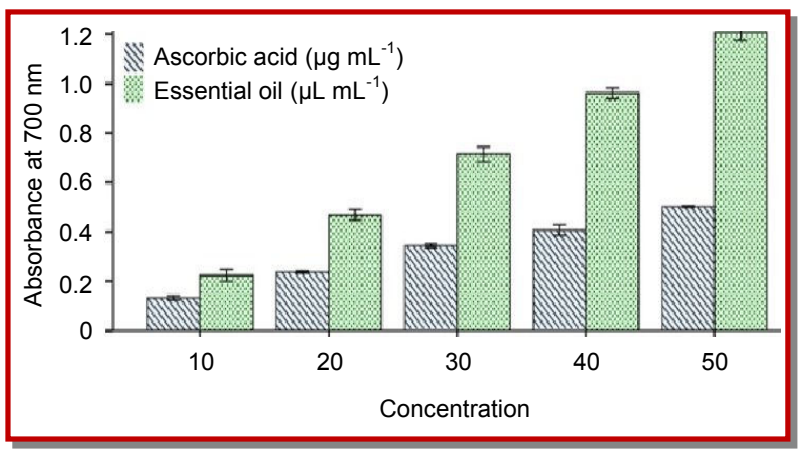

Figure 2: Reducing power of rhizome oil of H. matthewii and reference compound ascorbic acid (Values are mean \pm SD of two samples analyzed individually in triplicate)

scavenging activity of the oil and the reference compound ascorbic acid. Concentration at which the oil decreased $\mathrm{DPPH}$ radical by $50 \%$ ( $\mathrm{IC}_{50}$ value) was 31.5 $\mu \mathrm{L} / \mathrm{mL}$. Correspondingly, $\mathrm{IC}_{50}$ value for ascorbic acid, used as a standard, was $30.5 \mu \mathrm{g} / \mathrm{mL}$.

\section{Nitric oxide (NO) scavenging activity}

Anti-oxidant activity of the essential oil was further determined by inhibition of nitric oxide radicals is shown in Table III. The nitric oxide scavenging capacity of extracts and the reference compound ascorbic acid was increased with increasing concentration. The results of the study showed that a significant difference $(p<0.05)$ was observed between the two experimental conditions. A total of $50 \%\left(\mathrm{IC}_{50}\right)$ of the nitric oxide radicals was scavenged by essential oil at a concentration of $27.5 \mu \mathrm{L} / \mathrm{mL}$, whereas that of the ascorbate was $48 \mu \mathrm{g} / \mathrm{mL}$. The experimental analysis showed that, the essential oil of $H$. matthewii had good nitric oxide scavenging effect.

\section{Discussion}

The antibacterial activities of essential oils are wellknown. Recently, the antibacterial activity of essential oils of Buddleja asiatica, Caesalpinia bonducella, Ginkgo biloba and Ligustrum lucidum are reported (Bajpai et al,
2015; Bajpai et al, 2016; Khan et al., 2015; Shukla et al, 2016). Previous studies showed that multiplication of pathogenic Salmonella spp., Escherichia coli (O157:H7), Listeria monocytogenes, Helicobacter pylori and Mycoplasma pneumoniae were inhibited by essential oils (Burt, 2004). Monoterpenes are good antibacterial and antifungal agent (Jirovetz et al., 2005; Soković et al., 2010) in particular the oxygenated compounds (Kotan et al., 2007). The major component in the essential oil of $H$. matthewii was linalool an oxygenated monoterpene, followed by 4 -terpineol, $\beta$-pinene, camphene, borneol and a-pinene, together constitute $73 \%$ of the essential oil isolated. The earlier studies showed that linalool, $\beta$ pinene and 4-terpineol were found to be possessing good antibacterial properties against several microorganisms (Barel et al., 1991; Kotan et al., 2007; Park et al., 2012; Soković et al., 2010). Essential oil of $H$. matthewii showed a promising antibacterial activity might be attributed to these major constituents. Hence, essential oil from rhizomes of this plant can be used in the antibacterial formulations, which in turn broadens its applications in the pharmaceutical and other industries. Moreover, the broad-spectrum antibacterial activity of the essential oil of $H$. matthewii may perhaps due to the liposolubility of its constituents. It is a good indication of the antiseptic power of the essential oil isolated (Marino et al., 1999; Porter and Wilkins, 1999).

The anti-oxidant activity of essential oils is another biological property of great interest because they may have various industrial applications (Aruoma, 1998; Kamatou and Viljoen, 2010; Maestri et al., 2006). Reactive oxygen species (ROS) and reactive nitrogen species (RNS) are the two major classes of free radicals which oxidize various biomolecules and in turn lead to cellular damages and being responsible for diverse diseases even though they have important role in host defence mechanisms (Miguel, 2010). Again, the damaging effects are being increased by generating the peroxinitrite anion (ONOO-) after reacting with the superoxide anion radicals (Gomes et al., 2008; Kostka, 1995; Miyasaka and Hirata, 1997; Nagano, 1999). Therefore, molecules or agents which can inhibit the generation of $\mathrm{NO}$ have potential applications in the 
pharmaceutical industry.

Present investigation showed that the essential oil isolated from H. matthewii is a potent inhibitor and/or scavenger of DPPH and NO radicals. Linalool, a monoterpenoid possessing biological properties such as antibacterial and anti-oxidant activities (Liu et al., 2012), might be the major active molecule present in the oil of H. matthewii. Earlier studies showed that, linalool found to be a potent scavenger of DPPH radical, inhibit the production of $\mathrm{NO}$ radical and also showed bactericidal activities (Liu et al., 2012; Peana et al., 2006).

Anti-oxidant properties of essential oils such as reducing power, scavenging of free radicals, lipid peroxidation, chelating metal ions etc. are often come from their monoterpene hydrocarbons, oxygenated monoterpenes and sesquiterpenes (Loizzo et al., 2010; Tepe et al., 2005), hence the strong anti-oxidant activity of essential oil isolated from the rhizomes of $H$. matthewii may not only be related to linalool but also the sum of the effects of constituents in the essential oil. Therefore, the high anti-oxidant activity of this essential oil strengthens their application for possible use as natural anti-oxidants.

\section{Conclusion}

Analysis of the essential oil isolated from the dried rhizomes of $H$. matthewii revealed the presence of good amounts of monoterpenes especially oxygenated compounds. The antimicrobial and anti-oxidant properties of the oil recommend its use in pharmaceutical and other industrial products. The study helped in identifying, H. matthewii, a hitherto unexplored aromatic plant, as a novel natural source of linalool (45\%).

\section{Acknowledgement}

Indian Institute of Spices Research (IISR), Calicut, India, provided required facilities is gratefully acknowledged. We would like to thank Mr. Jomy Joseph for the technical help provided. Authors are thankful to the Department of Forests and Wildlife, Government of Kerala for granting permission to collect the plant materials.

\section{Conflict of Interest}

All authors have completed the ICMJE uniform disclosure form and declare no support from any organization for the submitted work.

\section{References}

Adams RP. Identification of essential oil components by gas chromatography/mass spectrometry. $4^{\text {th }}$ ed. IL, Allured Publishing Corporation, 2007.

Aruoma OI. Free radicals, oxidative stress, and anti-oxidants in human health and disease. J Am Oil Chem Soc. 1998; 75: 199 $-212$

Bajpai V, Sharma A, Baek K. Antibacterial mode of action of Ginkgo biloba leaf essential oil: Effect on morphology and membrane permeability. Bangladesh J Pharmacol. 2015; 10: $337-50$.

Bajpai V, Singh S, Mehta A. Chemical characterization and mode of action of Ligustrum lucidum flower essential oil against food-borne pathogenic bacteria. Bangladesh J Pharmacol. 2016; 11: 269-80.

Báez D, Pino JA, Morales D. Floral scent composition in Hedychium coronarium J Koenig analysed by SPME. J Essent Oil Res. 2011; 23: 64-67.

Barel S, Segal R, Yashphe J. The antimicrobial activity of the essential oil from Achillea fragrantissima. J Ethnopharmacol. 1991; 33: 187-91.

Bauer AW, Kibry WMM, Sherris JC, Turck M. Antibiotic susceptibility testing by a standardized single disc method. Am J Clin Pathol. 1966; 45: 493-96.

Bisht GS, Awasthi AK, Dhole TN. Antimicrobial activity of Hedychium spicatum. Fitoterapia 2006; 77: 240-42.

Burt S. Essential oils: Their antibacterial properties and potential applications in foods- a review. Int J Food Microbiol. 2004; 94: 223-53.

Gomes A, Fernandes E, Lima JLFC, Mira L, Corvo ML. Molecular mechanisms of anti-inflammatory activity mediated by flavonoids. Curr Med Chem. 2008; 15: 1586-605.

Jirovetz L, Buchbauer G, Denkova Z, Slavchev A, Stoyanova A, Schmidt E, Geissler M. Antimicrobial testings and gas chromatographic analysis of pure oxygenated monoterpenes 1,8-cineole, a-terpineol, terpinen-4-ol and camphor as well as target compounds in essential oils of pine (Pinus pinaster), rosemary (Rosmarinus officinalis), tea tree (Melaleuca alternifolia). Sci Pharm. 2005; 73: 27-39.

Johnson EI. The quantitative analysis of drugs. J Pharm Pharmacol. 1964; 16: 772.

Joshi S, Chanotiya CS, Agarwal G, Prakash O, Pant AK, Mathela CS. Terpenoid compositions anti-oxidant and antimicrobial properties of the rhizome essential oils of different Hedychium species. Chem Biodivers. 2008; 5: 299 309.

Joy B, Rajan A, Abraham E. Antimicrobial activity and chemical composition of essential oil from Hedychium coronarium. Phytother Res. 2007; 21: 439-43.

Kamatou GPP, Viljoen AM. A review of the application and pharmacological properties of a-bisabolol and a-bisabololrich oils. J Am Oil Chem Soc. 2010; 87: 1-7.

Khan F, Jan A, Khan N, Khan N, Khan S. GC/MS analysis, antimicrobial and in vitro anti-cholinesterase activities of the essential oil from Buddleja asiatica. Bangladesh J Pharmacol. 2015; 10: 891-95.

Kostka P. Free radicals (nitric oxide). Anal Chem. 1995; 67: 411 
$-16$

Kotan R, Kordali S, Cakir A. Screening of antibacterial activities of twenty-one oxygenated monoterpenes. $\mathrm{Z}$ Naturforsch C J Biosci. 2007; 62: 507-13.

Liu K, Chen Q, Liu Y, Zhou X, Wang X. Isolation and biological activities of decanal, linalool, valencene, and octanal from sweet orange oil. J Food Sci. 2012; 77: 1156-61.

Loizzo MR, Tundis R, Conforti F, Menichini F, Bonesi M, Nadjafi F, Frega N, Menichini, F. Salvia leriifolia Benth (Lamiaceae) extract demosntrates in vitro anti-oxidant properties and cholinesterase inhibitory activity. Nutr Res. 2010; 30: 823-30.

Maestri DM, Nepote V, Lamarque AL, Zygadlo JA. Natural products as anti-oxidants. In: Phytochemistry: Advances in research. Imperato F (ed). Kerala, Research Signopost, 2006, pp 105-35.

Mani B, Thomas TD. Evaluation of the anti-oxidant potential of Pittosporum dasycaulon Miq stem bark. Food Sci Biotechnol. 2014; 23: 539-45.

Marino M, Bersani C, Comi G. Antimicrobial activity of the essential oils of Thymus vulgaris L. measured using a bioimpedometric method. J Food Protect. 1999; 62: 1017-23.

Medeiros JR, Campos LB, Mendonca SC, Davin LB, Lewis NG. Composition and antimicrobial activity of the essential oils from invasive species of the Azores, Hedychium gardenarium and Pittosporum undulatum. Phytochemistry 2003; 64: 561-65.

Miguel MG. Anti-oxidant and anti-inflammatory activities of essential oils: A short review. Molecules 2010; 15: 9252-87.

Miyasaka N, Hirata Y. Nitric oxide and inflammatory arthritides. Life Sci. 1997; 61: 2073-81.

Nagano T. Practical methods for detection of nitric oxide. Luminescence 1999; 14: 283-90.

Park S, Lim YK, Freire MO, Cho E, Jin D, Kook J. Antimicrobial effect of linalool and a-terpineol against periodontopathic and cariogenic bacteria. Anaerobe 2012; 18: 369-72.

Peana AT, Marzocco S, Popolo A, Pinto A. (-)-Linalool inhibits in vitro NO formation: Probable involvement in the antinociceptive activity of this monoterpene compound. Life
Sci. 2006; 78: 719-23.

Porter NG, Wilkins AL. Chemical, physical and antimicrobial properties of essential oils of Leptospermum scoparium and Kunzea ericoides. Phytochemistry 1999; 50: 407-15.

Raj G, Dan M, George V, Sethuraman MG. Studies on chemical composition of essential oils from leaf and inflorescence of Hedychium larsenii M. Dan \& Sathish. J Essent Oil Res. 2013; 25: 33-38.

Raj G, Dan M, Shiburaj S, Sethuraman MG, George V. Chemical composition and antibacterial activity of the rhizome oil of Hedychium larsenii. Acta Pharm. 2005; 55: 31520 .

Sabulal B, George V, Dan M, Pradeep NS. Chemical composition and antimicrobial activities of the essential oils from the rhizomes of four Hedychium species from South India. J Essent Oil Res. 2007; 19: 93-97.

Sakhanokho HF, Sampson BJ, Tabanca N, Wedge DE, Demirci B, Can Baser KH, Bernier UR, Tsikolia M, Agramonte NM, Becnel JJ, Chen J, Rajasekaran K, Spiers JM. Chemical composition, antifungal and insecticidal activities of Hedychium essential oils. Molecules 2013; 18: 4308-27.

Shukla S, Majumder R, Ahirwal L, Mehta A. Proposed mechanism of antibacterial mode of action of Caesalpinia bonducella seed oil against food-borne pathogens. Bangladesh J Pharmacol. 2016; 11: 257-63.

Soković M, Glamočlija J, Marin PD, Brkić D, van Griensven LJLD. Antibacterial effects of the essential oils of commonly consumed medicinal herbs using an in vitro model. Molecules 2010; 15: 7532-46.

Tepe B, Daferera D, Sokmen A, Sokmen M, Polissiou M. Antimicrobial and anti-oxidant activities of essential oil and various extracts of Salvia tomentosa Miller (Lamiaceae). Food Chem. 2005; 90: 333-40.

Thomas S, Mani B, Britto SJ. A new species of Hedychium (Zingiberaceae) from the southern Western Ghats, India. Webbia 2015; 70: 221-25.

Yen GC, Duh PD. Anti-oxidative properties of methanolic extracts from peanut hulls. J Am Oil Chem Soc. 1993; 70: 383 $-86$. 


\section{Your feedback about this paper}

1. Number of times you have read this paper 0

2. Quality of paper Click

3. Your comments

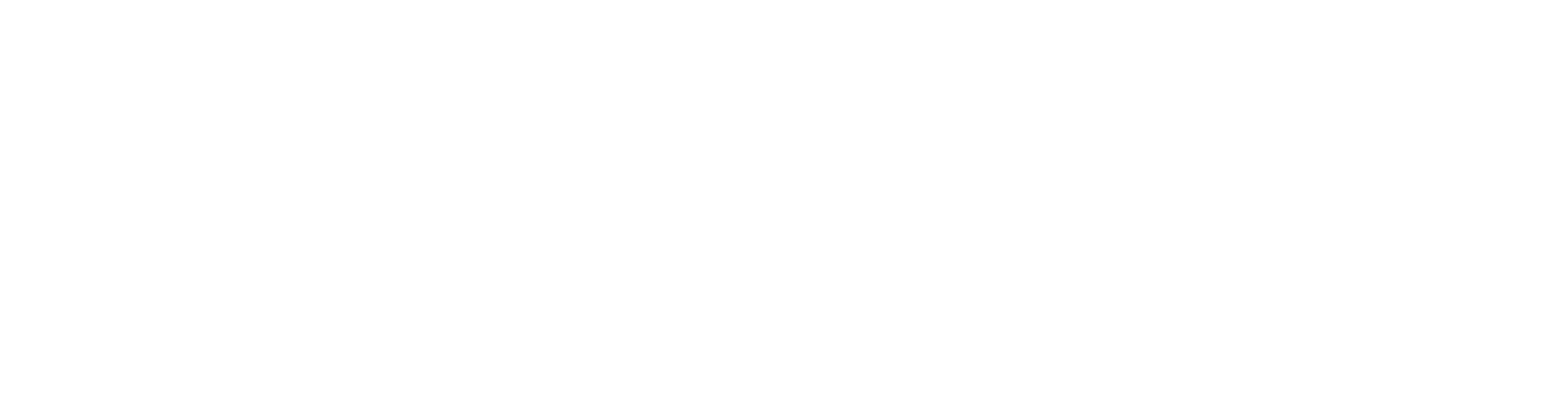

